\title{
Sulphur-oxidising bacteria and haemoglobin in gills of the bivalve mollusc Myrtea spinifera
}

\author{
P.R.Dando ${ }^{1}$, A. J. Southward ${ }^{1}$, E. C.Southward ${ }^{1}$, N. B. Terwilliger ${ }^{2} \&$ R. C. Terwilliger ${ }^{2}$ \\ ${ }^{1}$ Marine Biological Association, Citadel Hill, Plymouth PL1 2PB, United Kingdom \\ ${ }^{2}$ Institute of Marine Biology, University of Oregon, Charleston, Oregon 97420, USA
}

\begin{abstract}
The gills of Myrtea spinifera carry large numbers of Gram-negative bacteria within the epithelial cells of the subfilamentar region and contain elemental sulphur. Haemoglobin which has a high affinity for oxygen is present in the gill tissue. Homogenates of gill tissue fix carbon dioxide via ribulosebisphosphate carboxylase and contain 3 enzymes concerned in the oxidation of sulphur, adenylylsulphate reductase, sulphate adenylyltransferase and sulphate adenylyltransferase (ADP). Fixation of carbon dioxide by whole gills is enhanced by free sulphide. Whole gills accumulate labelled sulphur when supplied with $\mathrm{Na}_{2}{ }^{35} \mathrm{~S}$, and a major proportion of the labelled sulphur is metabolized to non-volatile compounds or is bound to the tissues. The bacteria are evidently chemoautotrophs and presumably obtain energy for fixation of carbon dioxide by oxidation of reduced sulphur compounds. The haemoglobin is not apparently involved in transport of sulphide but may control oxygen tension close to the bacteria. The sediment in which the bivalves live is low in sulphide compared with some coastal muds and the hydrothermal vents. The interstitial water contains less than $1 \mu \mathrm{M}$ of dissolved sulphide and the sediment releases less than $700 \mu \mathrm{moles} \mathrm{dm}^{-3}$ of dissolved sulphide when treated with dilute acid. Habitats with similar low concentrations of dissolved sulphide are widespread in nature. An ability to exploit such low levels of reduced sulphur must be mutually advantageous to host and bacteria, though as yet we have no direct evidence for transfer of organic matter from bacteria to host. To obtain sufficient energy for growth and maintenance of the association, the bacteria must have access to the sediment-bound sulphide.
\end{abstract}

\section{INTRODUCTION}

Sulphur-oxidising bacteria are widespread in sediments and waters where oxic and anoxic conditions meet (Jørgensen 1977, 1982). They obtain energy by oxidation of reduced sulphur compounds and fix carbon dioxide to form organic carbon compounds. A new site for such activity was found in deep-sea hydrothermal vents in 1977 . The vent waters contain high concentrations of $\mathrm{H}_{2} \mathrm{~S}$ and support growth of sulphuroxidising bacteria (Jannasch \& Wirsen 1979). The dense communities of animals which surround some of the vents were at first assumed to feed on bacteria suspended in the vent water, but it soon appeared that one of the most abundant creatures was a large gutless worm-like animal (Riftia pachyptila Jones) which cannot take in particulate food. This animal contained vast numbers of endosymbiotic bacteria, probably sulphide oxidizers, which contributed to the nutrition of their host (Cavanaugh et al. 1981). Two large-sized species of bivalve mollusc, abundant around vents, have also been found to carry similar bacteria in their gills. The bacteria may contribute to the bivalves' nutrition, although these animals do have a normal filter feeding mechanism and a digestive system (Felbeck et al. 1981, Cavanaugh 1983). Animals living in other marine environments with high concentrations of free sulphide, such as sewage outfalls and seagrass beds, also contain symbiotic sulphur bacteria. As a consequence it has been assumed that a fairly high concentration of sulphide is a prerequisite for development of such an association. However, there are other gutless worms (Pogonophora), related to Riftia, containing symbiotic bacteria capable of fixing $\mathrm{CO}_{2}$ (Southward et al. 1981, Southward 1982). Free sulphide is barely detectable in the sediments inhabited by these pogonophores and other energy sources, including methane, hydrogen and ammonia, have been investigated in the search for their method of nutrition.

A clue to the nutrition of these pogonophores may be obtained from a study of other kinds of animals in the same habitat. In particular, the bivalve superfamily 
Lucinacea was suggested (C. M. Cavanaugh pers. comm.) as a probable source of animals with endosymbiotic bacteria. This superfamily contains a number of species that are typically found in the anoxic layer of sediments and which display unusual gill, palp and alimentary canal structures that have puzzled previous investigators of their functional anatomy (Allen 1958). Recently it has been found that 2 lucinaceans, Lucinoma annulata and Codakia orbicularis, carry endosymbiotic bacteria in their gills, comparable to those also found in the protobranch bivalve Solemya velum (Cavanaugh 1983, Berg \& Alatolo 1984).

Three lucinaceans, Lucinoma borealis (L.), Myrtea spinifera (Montagu) and Thyasira flexuosa (Montagu), co-occur with a rich population of the pogonophore Siboglinum fiordicum Webb in a Norwegian fjord (Southward et al. 1979). We have now found that all 3 bivalves contain bacterial symbionts. The bivalves are more convenient to study than small pogonophores. This paper describes the symbiosis in $M$. spinifera, including the way in which the association appears to be able to exploit the very low concentration of free sulphide in its habitat. Other papers will deal with $L$. borealis, $T$. flexuosa and $S$. fiordicum. It is of great interest to discover such a capability, and to consider the possibility that the very widespread low sulphide environments in the sea (Volkov \& Rozanov 1983) may be utilized by similar symbiotic associations between sulphide-oxidizing bacteria and animals.

\section{MATERIAL AND METHODS}

We have studied a rich population of Myrtea spinifera (shell length 6 to $12 \mathrm{~mm}$ ) living in muddy sand at $33 \mathrm{~m}$ depth in Ypsesund, a side-branch of Herdlafjorden, near Bergen (Norway), where densities can reach $25 \mathrm{~m}^{-2}$. Other bivalves present include Lucinoma borealis, Thyasira flexuosa, Arctica islandica (L.) and Corbula gibba (Olivi). Specimens were collected with a modified Van Veen grab and kept in muddy sand from the habitat under the cool flowing circulation water at the Institutt for Marinbiologi, University of Bergen. A number of specimens were brought back to Plymouth (England) and kept in a constant-temperature room at $8{ }^{\circ} \mathrm{C}$. Observations were made on the burrowing activity of the bivalves in test tubes filled with sediment. Dissected material was assessed for gill colour and appearance.

Sediment sampling. A gravity corer, fitted with $60 \mathrm{~mm}$ internal diameter PVC liners, was used to collect sediment samples. The cores were sealed with bungs as soon as possible after retrieval. Surface samples of sediment were taken through the top flap of the Van Veen grab as soon as it reached the deck. Cores were handled in a glove bag in an atmosphere of either oxygen-free nitrogen or helium. Interstitial water was collected either by pressure filtration, under nitrogen, through $0.2 \mu \mathrm{m}$ cellulose acetate filters, or by centrifugation after addition of 1, 1,2-trichlorotrifluoroethane (Kinniburgh \& Miles 1983). Dissolved sulphide was estimated by the methylene blue technique (Cline 1969), acid reagent being added to the samples immediately after collection. Acid-labile sulphide was fixed and trapped as described by Munson (1977) and estimated colourimetrically by the methylene blue technique. Thiosulphate, trithionate and tetrathionate were determined in pore water using the procedure of Kelly et al. (1969). Sub-samples of the cores $\left(5 \mathrm{~cm}^{3}\right)$ were weighed and dried to constant weight at $110^{\circ} \mathrm{C}$ to determine water content and then heated to $450^{\circ} \mathrm{C}$ to constant weight to estimate organic content. Iron and manganese were measured by atomic absorption spectroscopy after extraction with cold $10 \% \mathrm{HCl}$. Sediment temperature and a measure of the Redox potential were obtained by pushing probes into freshly extruded cores and Van Veen grab samples. A Radiometer oxygen electrode was used in conjunction with an M.B.A. portable oxygen analyser to provide an approximate measure of oxygen content of the upper few $\mathrm{cm}$ of sediment.

Enzyme assay. Tissues were dissected out and rinsed with filtered sea water before homogenization in 100 to $300 \mu \mathrm{l}$ of ice-cold distilled water in an all glass PotterElvehjem homogenizer. Assays were carried out at $12{ }^{\circ} \mathrm{C}$, the highest temperature the animals are likely to experience at Ypsesund, and buffers were adjusted to this temperature. Adenylylsulphate was prepared enzymatically from sodium sulphate labelled with ${ }^{35} \mathrm{~S}$ (Amersham) as described by Tsang et al. (1976). Purity of the preparation was checked by paper electrophoresis at pH 5.8 (Baddiley et al. 1957) and corrections were made for sulphate formed by degradation of the adenylylsulphate. ${ }^{35} \mathrm{~S}$ labelled adenylylsulphate was used for assay of adenylylsulphate reductase (EC. 1.8.99.2) following the procedure of Peck et al. (1965). The reaction medium of $500 \mu \mathrm{l}$ was $160 \mathrm{mM}$ imidazole, $8 \mathrm{mM}$ EDTA, $0.25 \mathrm{mM} \beta$-mercaptoethanol, $4 \mathrm{mM}$ methylviologen, $5 \mathrm{mM}$ sodium dithionite and $5 \mu \mathrm{M}$ adenylylsulphate $\left({ }^{35} \mathrm{~S}\right.$ labelled), $\mathrm{pH}$ 7.0. Incubations were carried out in an atmosphere of helium in Warburg flasks. At the end of the experiment $800 \mu$ moles of sulphuric acid were tipped in from one side arm and 8 $\mu$ moles of sodium sulphite from the other. The sulphur dioxide was trapped in 100 moles of sodium hydroxide in the centre well. Negligible activity was observed in the absence of methyl viologen.

Sulphate adenylyltransferase (EC. 2.7.7.4) and sulphate adenylyltransferase (ADP) (EC. 2.7.7.5) were assayed in a $140 \mu \mathrm{l}$ reaction medium of $70 \mathrm{mM}$ imidazole, $7 \mathrm{mM}$ EDTA, $18 \mu \mathrm{M}$ adenylylsulphate 
labelled with ${ }^{35} \mathrm{~S}$ and either $3 \mathrm{mM}$ sodium pyrophosphate or $3 \mathrm{mM}$ sodium triphosphate, $\mathrm{pH} 7.5$. The reaction was stopped by addition of $50 \mu \mathrm{l} 0.5 \mathrm{M}$ barium chloride, and $50 \mu \mathrm{l} 20 \mathrm{mM}$ sodium sulphate was added as a carrier, to precipitate released sulphate. The barium sulphate was removed by centrifuging and aliquots of the supernatant were counted for unchanged adenylylsulphate by liquid scintillation spectrometry. Controls containing enzyme but lacking added phosphate or pyrophosphate, when precipitated, showed counts similar to controls containing phosphate or pyrophosphate but lacking enzyme.

Ribulosebisphosphate carboxylase (EC. 4.1.1.39) was assayed in a $70 \mu \mathrm{l}$ reaction mixture of $43 \mathrm{mM}$ Tris, $20 \mathrm{mM}$ magnesium chloride, $20 \mathrm{mM}$ reduced glutathione, $82 \mathrm{mM}$ sodium bicarbonate, $0.6 \mathrm{mM}$ $\mathrm{NaH}^{14} \mathrm{CO}_{3}$ and $5 \mathrm{mM}$ ribulose bisphosphate, $\mathrm{pH}$ 8.0. Oxygen was not excluded during the assay. The reaction was stopped with $200 \mu \mathrm{l}$ glacial acetic acid. After transferring the mixture to glass vials it was evaporated to dryness at $55^{\circ} \mathrm{C}$, reacidified with $200 \mu \mathrm{l}$ glacial acetic acid and redried before counting. Before use the ${ }^{14} \mathrm{C}$ labelled sodium bicarbonate supplied by Amersham was dissolved in $1 \mathrm{mM}$ sodium hydroxide and exposed for $24 \mathrm{~h}$ to UV light to remove non volatile ${ }^{14} \mathrm{C}$ compounds. After this treatment, controls incubated without ribulose bisphosphate showed negligible fixation of ${ }^{14} \mathrm{CO}_{2}$

Elemental sulphur. Gills were fixed in $4 \%$ formaldehyde in distilled water containing $2 \%$ cadmium chloride. Elemental sulphur was extracted with carbon disulphide and reacted with cyanide before measurement as thiocyanate (Fliermans \& Brock 1973).

Fixation of sulphur. Fresh whole gills were incubated in filtered sea water containing approximately $18 \mu \mathrm{M} \mathrm{l}^{-1}$ sodium sulphide (Amersham SJ. 21, Lot' 4/84, specific activity $16.9 \mu \mathrm{Ci} / \mu \mathrm{M}$, purity not specified) of which about $1 \%$ was ${ }^{35} \mathrm{~S}$. After incubation the gills were rinsed three times with filtered sea water and extracted in alkaline $80 \%$ methanol. In some of the gills elemental sulphur was dissolved out with carbon disulphide and any ${ }^{35} \mathrm{~S}$ counted. Other gills were digested in 'NCS Tissue Solubilizer' and the total 'bound' ${ }^{35} \mathrm{~S}$ counted. Aliquots of the methanol extract were counted in 'Instagel'. Other aliquots were subjected to electrophoresis in $1 \%$ triethylamine ( $\mathrm{pH} 12$ ), before or after heating with glacial acetic acid to remove volatile sulphur compunds, or were subjected to thin layer chromatography in isopropanol:formic acid:water $(6: 1: 1 \mathrm{v} / \mathrm{v})$. Labelled compounds were detected by scanning the chromatograms and electrophoretograms with a gas flow counter, by autoradiography and (for electrophoretograms) by counting $5 \mathrm{~mm}$ strips by liquid scintillation.

Fixation of bicarbonate in presence of sulphide.
Fresh whole gills were incubated in filtered sea water containing known amounts of $\mathrm{NaH}^{14} \mathrm{CO}_{3}$, with and without addition of buffered sodium sulphide solution. A parallel control, without gill, was monitored for dissolved sulphide, and additions of sulphide were made to the experimental vessels to maintain the desired level (ca. 20 to $30 \mu \mathrm{M} \mathrm{l}^{-1}$ ). At the end of the experiment the level of sulphide in the experimental vessels was checked. The gills were washed 3 times in filtered sea water, weighed, and immersed for $1 \mathrm{~h}$ in sea water acidified to $\mathrm{pH} 2.5$ with hydrochloric acid, to remove bicarbonate. After another rinse the gills were digested in 'Protosol' at $55^{\circ} \mathrm{C}$, and the resulting solution counted in 'Instagel'.

Protein separation. Gill proteins, including haemoglobin, were extracted from $133.6 \mathrm{mg}$ wet weight of gill tissue removed from 12 Myrtea spinifera. The gills were homogenized in ice-cold buffer, pH 7.5, $(50 \mathrm{mM}$ Tris, $100 \mathrm{mM}$ sodium chloride, $50 \mathrm{mM}$ magnesium chloride and $10 \mathrm{mM}$ calcium chloride), with an allglass Potter-Elvehjem homogenizer. The homogenate was centrifuged at $12000 \mathrm{~g}$ and the pellet was rehomogenized in the same buffer and centrifuged again. The 2 supernatants were pooled and chromatographed at $2^{\circ} \mathrm{C}$ on a $1.3 \times 51 \mathrm{~cm}$ column of Sephadex G-100, in equlibrium with the extraction buffer. Binding of sulphide to the column fractions was investigated by dialysing $500 \mu \mathrm{l}$ aliquots against $10 \mu \mathrm{M}$ sodium suiphide labelled with ${ }^{35} \mathrm{~S}$, in the $\mathrm{pH} 7.5$ buffer. After $1 \mathrm{~h}$ aliquots were removed from the dialysis sacs for liquid scintillation counting. Oxygen binding properties of the column-purified haemoglobin were measured spectrophotometrically (Benesch et al. 1965). Samples were dialysed overnight versus the appropriate buffer before analysis. Sodium dodecylsulphate (SDS) gel electrophoresis was carried out on $14 \%$ polyacrylamide slabs (Laemmli 1970).

Microscopy. Gills were fixed in $2.5 \%$ glutaraldehyde in $0.1 \mathrm{M}$ phosphate buffer, $\mathrm{pH} 7.3$, with $14 \%$ sucrose, and also in $2.5 \%$ glutaraldehyde in sea water. Small pieces were postfixed in $1 \%$ osmic acid in either phosphate buffer or sea water. All were dehydrated in ethanol series and embedded in Spurr resin. Thin sections were stained with uranyl acetate and lead citrate and examined in a Phillips 300 electron microscope. Semi-thin sections were stained with toluidine blue for light microscopy and fresh pieces of gill were examined by phase contrast light microscopy.

\section{RESULTS}

\section{General anatomy and behaviour}

Anatomy and behaviour of some lucinids were described by Allen (1953), who noted the ciliary cur- 
rents of the gill and mantle of Myrtea spinifera but did not describe its burrowing or the histology of the gill. Captured specimens burrow readily, under laboratory conditions, by digging with the foot, in the same way as other lucinids, to reach a depth of 10 to $50 \mathrm{~mm}$ below the surface of the sediment. Like other lucinids, $M$. spinifera uses the vermiform tip of the foot to construct a narrow, mucus-lined 'inhalent tube' which allows it to draw water from the surface. The water enters the mantle cavity in front of the anterior adductor muscle (Fig. 1). The inlet tube formed in the laboratory can be

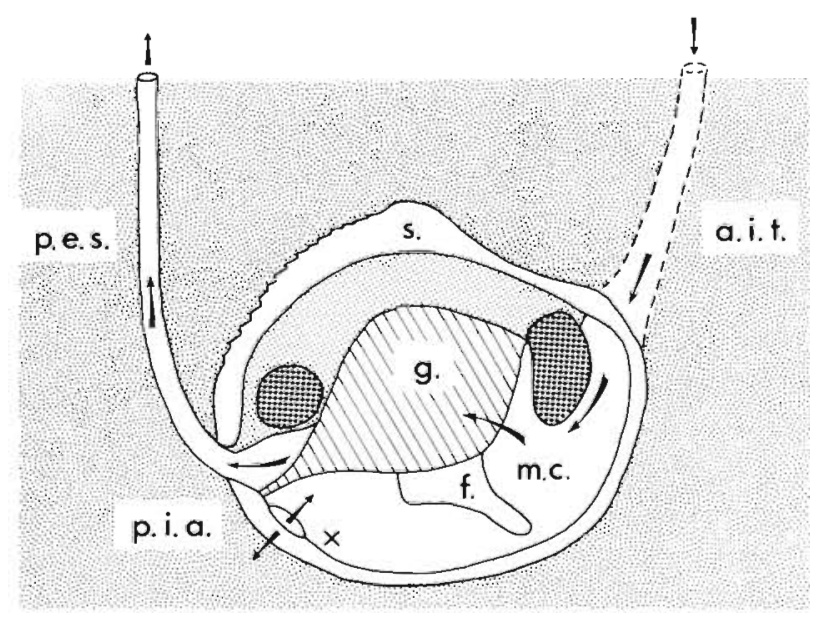

Fıg. 1. Myrtea spınifera in sediment (diagrammatıc). Arrows show direction of water flow. Dense stıpple: adductor muscles; a.i.t.: anterior inhalent tube; f.: foot; g.: gilli m.c.: mantle cavity; p.e.s.: posterior exhalent siphon; p.i.a.: posterior inhalent aperture; s.: shell; $\mathrm{x}$ : place where pseudofaeces collect

readily distinguished by its rust-coloured lining of oxidised iron, which contrasts well with the surrounding black, anoxic sediment (Fig. 2). Freshly collected individuals have a similar rust-brown patch at the anterior end of the shell where the inhalent tube adheres. Under laboratory conditions the undisturbed animals form a new inhalent tube, in a different position, every few days. In addition to the inhalent tube of sand grains and mucus, there is a posterior exhalent siphon, with a muscular wall, that can be extended out of the posterior end of the shell and upward to the sediment surface. Below the base of this exhalent siphon, where many bivalves have an inhalent siphon, lucinids have only a small inhalent aperture (Fig. 1). We are not sure yet of the depth at which $M$. spinifera lives at Ypsesund, since no bivalves were taken in the corer, but if they live at the depths to which they burrow in the laboratory, then the surrounding sediment will have an uncorrected redox reading of $-200 \mathrm{mV}$, or lower, and oxygen levels will be below those detectable with portable oxygen analysers. Hence any water entering through the posterior inha-

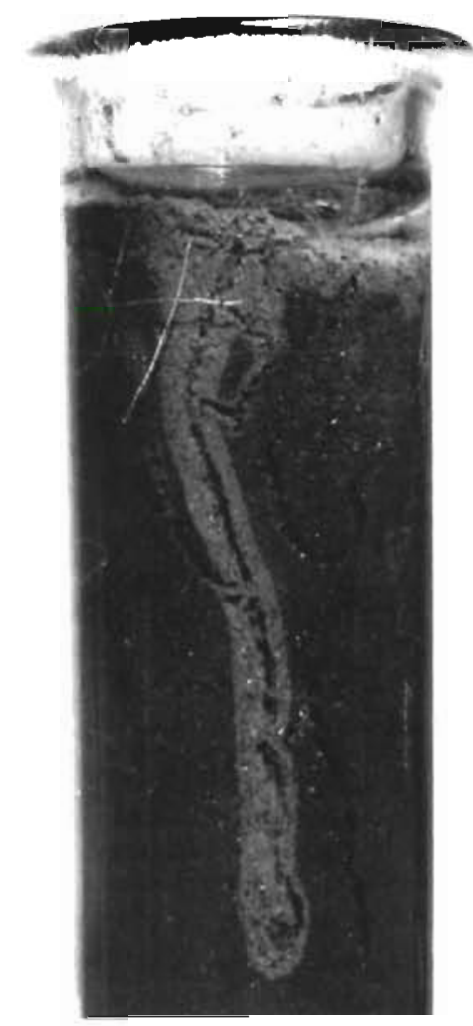

Fig. 2. Myrtea spinifera burrowing in dark muddy sand in a $15 \mathrm{~mm}$ diameter test tube; note light colour around inhalent tube, due to oxidation

lent aperture will be pore water from the sediment, containing sulphide and other reduced compounds.

\section{Site of symbionts}

When the living shell is opened, the foot and visceral mass can be seen flanked by 2 thick dark red gills (Fig. $3 \mathrm{~A})$. The foot is white, but additional red pigment is present in the posterior adductor muscle, the base of the exhalent siphon, and the nerve ganglia. Each of the gills is a single demibranch, not a pair of demibranchs as in most bivalves (Atkins 1937). The gills represent $22.6 \pm 3.6$ (S.D.) \% of the total body tissue wet weight (11 specimens). A gill of Myrtea spinifera resembles a flat pocket, made up of parallel V-shaped filaments which are connected by rows of interfilamentar bridges to form a pair of grid-like lamellae, joined at the bottom (Fig. 3A, B). The gill lamellae are joined together by plate-like bridges which divide the internal space of the gill into narrow vertical channels which open into a continuous space between gill and visceral mass at the upper end of the gill, extending posteriorly to the base of the exhalent siphon. The main inflow of water to the mantle cavity is through the 


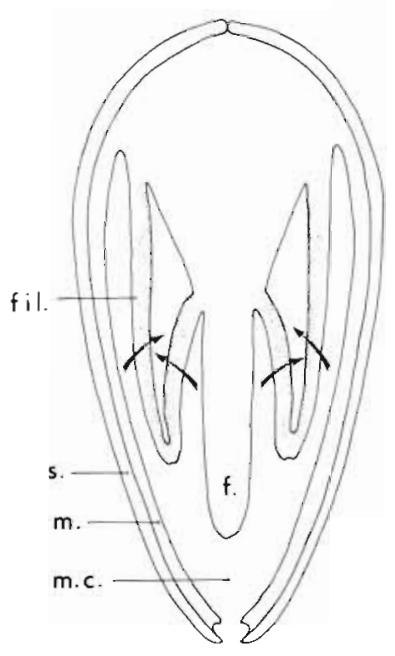

A

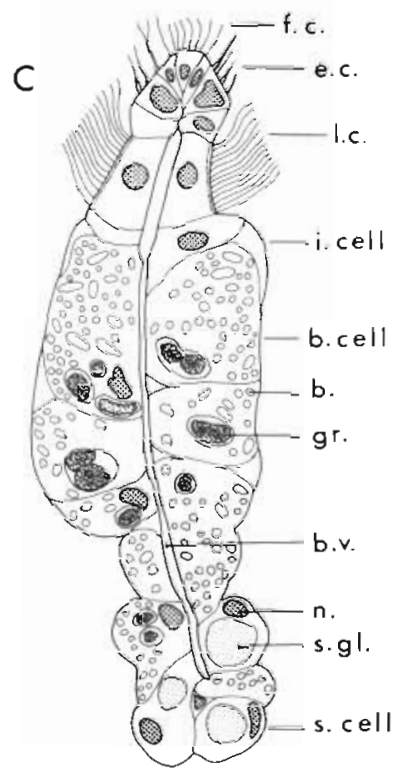

Fig. 3. Myrtea spinifera. (A) Vertical section; arrows: direction of water flow; stipple: position of bacteriocytes. (B) Section through both gill lamellae; arrows: direction of water flow; stipple: position of bacteriocytes. (C) T.S. gill filament. b.: bacterium; b.cell: bacteriocyte; b.v.: blood vessel; e.c.: eulaterofrontal cilia; f.: foot; f.c.: frontal cilia; Fil.: filament; f.p.: filament proper; gr.: brown granule; i.cell: intercalary cell; i.f.b.: interfilamentar bridge; j.l.b.: interlamellar bridge; l.c.: lateral cilia; m.: mantle; m.c.: mantle cavity; n.: nucleus; s.: shell; s.cell: storage cell; s.f.: subfilamentar region; s.gl.: storage globule

anterior inhalent tube (Fig. 1). Water is propelled between the gill filaments by the lateral cilia (Fig. 3C) and flows up the internal channels to the dorsal space (Fig. 3 A) and then out via the exhalent siphon (Fig. 1). Particles are filtered off by the cilia on the outer margins of the gill filaments, transported by ciliary currents and sorted so that food particles reach the mouth and rejected particles accumulate as pseudofaeces close to the posterior inhalent aperture (Allen 1958). Any water entering through this aperture will mix in the mantle cavity with the main anterior inflow and pass through the gill. Allen considered that the chief function of the posterior inhalent aperture would be the intermittent disposal of pseudofaeces in the opposite direction. True faeces are extruded from the anus into the exhalent current above and behind the gill and carried out through the exhalent siphon.

The ciliated outer surface of the gill is transparent and the dark red colour shows through from the inner parts of the filaments. Light microscope examination of slices of fresh gill shows that the epidermal cells of the inner parts of the filaments and the interlamellar bridges are inhabited by large numbers of bacteria. Several kinds of inclusion can be seen: (a) colourless, oval to oblong or rod-shaped bacteria; (b) irregular brown and yellow granules; (c) red pigment in separate globules; and (d) a scattering of minute refractile bodies that give the cells a whitish appearance in reflected light and are particularly abundant in the areas of gill that look whitish in the freshly opened animal, chiefly at the posterior end of the gill. The bacteria can be examined in more detail where damaged cells have released their contents. At least some of the refractile bodies can be seen to be within the bacteria.

From this description it can be inferred that the bacteria-containing cells (bacteriocytes) almost completely line the internal spaces of the gill, and will be exposed to a regular current of water, from which particles have been filtered, whenever the animal is pumping water through the gill (Fig. 3A, B). When the inhalent tube and/or the exhalent siphon is closed, they will be in a stagnant situation, with decreasing oxygen.

\section{Fine structure of gill filaments}

The outer ciliated region, or gill filament proper, is similar to that of other bivalves; only the sub-filamentar region is specialized. The epidermis of this region contains 3 types of cell: bacteriocytes, intercalary cells and storage cells. Apparently, mucus cells are absent. The bacteriocytes are the largest and most abundant of the cell-types (Fig. 3C). They are roughly cubical, with a broad base and an outer surface covered with short microvilli. Their cytoplasm is uniformly fine-grained and contains numerous vacuoles enclosing single bacteria (occasionally 2) (Fig. 4). Some larger vacuoles 


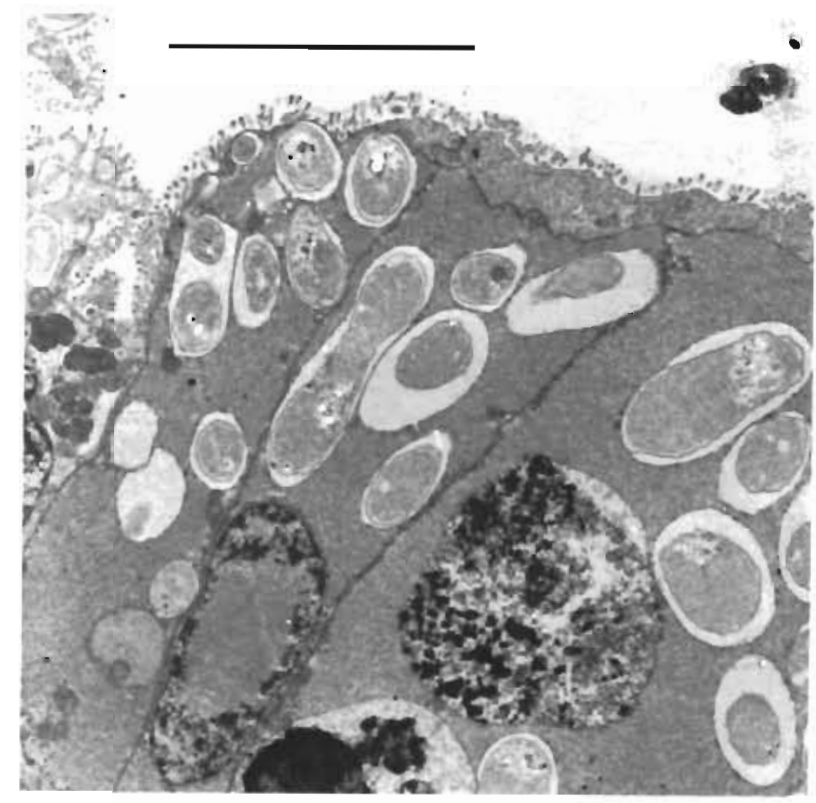

Fig. 4. Myrtea spinifera. Transmission electron micrograph of transverse section of gill filament, showing bacteriocytes partly covered by thin extension of intercalary cell. Note: bacteria in vacuoles; bacteriocyte nucleus, lower left; brown granules, lower centre. Scale bar $=10 \mu \mathrm{m}$

contain varied electron-dense material, which tends to break on cutting and may be rather hard. This corresponds to the brown and yellow granules. Scarce, small, mitochondria lie close to the cell borders. The basal nuclei are unusual in having a large central area clear of chromatin. Possibly this is the location of the haemoglobin concentration seen in living cells (cf. vertebrate erythrocytes, Fawcett 1966). Intercalary cells occur among the bacteriocytes; they are narrower and less electron-dense than the bacteriocytes. The base is narrow but the cell spreads out at the surface of the epidermis to form a thin layer partly covering the neighbouring bacteriocytes (Fig. 4). The short microvilli resemble those on the bacteriocytes and all are enveloped by a thin glycocalyx. The cytoplasm contains more mitochondria, small vacuoles and other inclusions than that of the bacteriocytes. The nucleus lies in the outer part of the cell. Storage cells are dropshaped, with narrow base and rounded outer side (Fig. $3 \mathrm{C}$ ). These have a smooth surface membrane without microvilli. They are filled with large globular inclusions of electron-dense homogeneous material, bounded by a thin membrane. The cytoplasm contains more obvious endoplasmic reticulum and Golgi membranes than the other 2 cell types. The intracellular globules stain deep blue with toluidine blue in semithin resin sections, while fresh globules are colourless and transparent. They are insoluble in water, ethanol or acetone and do not take up lipid stains. It is probable, therefore, that the storage material is protein.
The central blood space of the subfilamentar region contains haemocytes, including phagocytes carrying granular material similar to the brown granules in the bacteriocytes. This may be waste material which could be disposed of via the digestive system as in other bivalves. There are no haemoglobin-containing cells (erythrocytes) in the blood of Myrtea spinifera.

\section{Fine structure of bacteria}

The best preservation of internal detail of the bacteria was found in gill material fixed in glutaraldehyde in phosphate buffer with sucrose, post fixed in $\mathrm{OsO}_{4}$ (p.87). There is a wide range of bacterial sizes in any bacteriocyte, the largest found are $2.8 \times 9 \mu \mathrm{m}$; the usual range is from about $2.5 \times 6.5$ to $0.4 \times 4 \mu \mathrm{m}$. More than 1 species of bacterium may be present, but the internal details are so similar in the different sizes that it seems more probable that they represent development stages of 1 species. The bacterial cell-wall is thin, about $20 \mathrm{~nm}$, and 2 dense layers can be seen, an outer layer and a cytoplasmic membrane. Finer details have not been observed, but the general structure corresponds to that described for typical Gram-negative bacteria. The cytoplasmic membrane is extended to surround small spherical or lens-shaped vesicles 0.1 to 0.5 $\mu \mathrm{m}$ in diameter (Fig. 5), which probably represent the

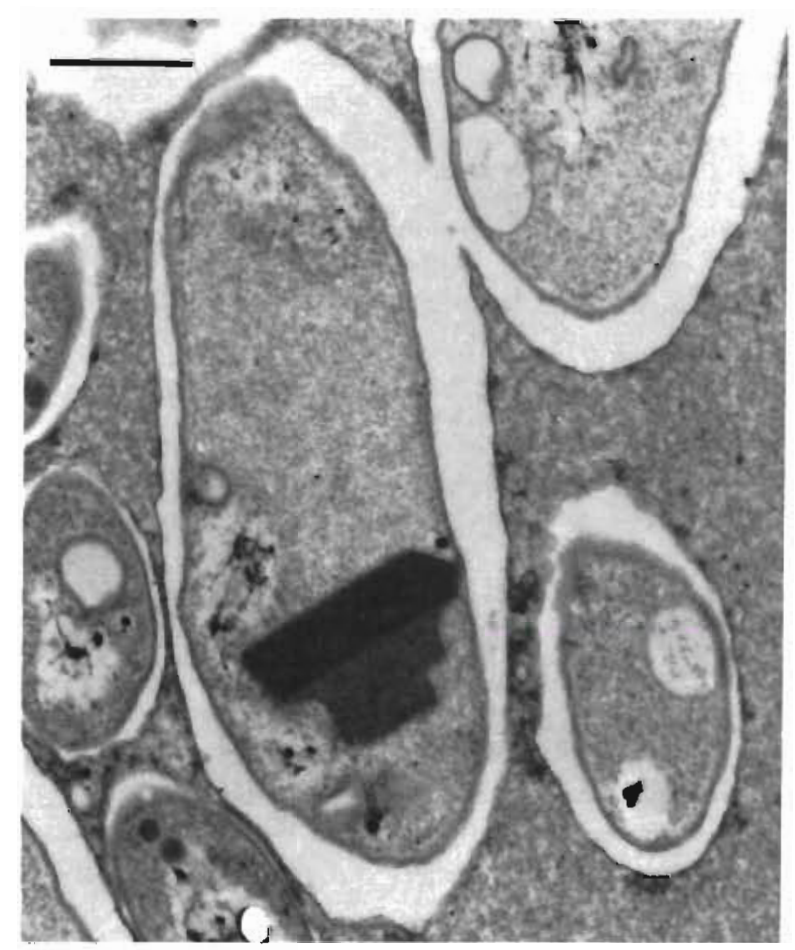

Fig. 5. Myrtea spinifera. Transmission electron micrograph showing bacterial symbionts, various sizes. Note membranebound vesicles in most individuals, smaller dark reticulate bodies in 2 on left. Scale bar $=1 \mu \mathrm{m}$ 
small refractile bodies seen with the light microscope. Their contents are preserved during glutaraldehyde fixation but lost during dehydration with ethanol, methanol or acetone, and are quite likely to be elemental sulphur. Other membrane-bound bodies with reticulate, electron-dense contents 0.1 to $0.16 \mu \mathrm{m}$ diameter) sometimes lie close to the 'sulphur' vesicles, but can occur separately. In some of the larger bacteria there are flat electron-dense crystals, in stacks of 2 or 3 (Fig. 5), possibly without a limiting membrane. The densest of these seem to be homogenous, while the less dense have a layered structure. The largest measured are $1.3 \mu \mathrm{m}$ long, they may be square, but the exact shape is difficult to determine from sections. The bacterial cytoplasm is filled with irregular particles about 30 to $50 \mathrm{~nm}$ in diameter, which may be clumped ribosomes or perhaps glycogen particles. Single, denser ribosomes about $20 \mathrm{~nm}$ diameter are visible in a few bacteria. A central core of less dense nucleoplasm extends through most of the length of the smaller bacteria, but is restricted to one end or one side of the larger bacteria (Fig. 4 \& 5). This region contains electron-dense DNA strands and also very dense spherical particles, 30 to $100 \mathrm{~nm}$ diameter, which are probably polyphosphate (volutin) granules. Thin sections tend to break at these granules. Carboxysomes have not been seen and intracytoplasmic membranes are rare, apart from those surrounding the vesicles and the reticulate granules.

\section{Enzyme activities}

The activities of ribulosebisphosphate carboxylase, adenylylsulphate reductase, sulphate adenylyltransferase and sulphate adenylyltransferase (ADP) for tissues of Myrtea spinifera and for the gills of Arctica islandica and Corbula gibba are given in Table 1.
Table 2. Myrtea spinifera. Ribulosebisphosphate carboxylase activity in gills compared with spinach leaf, on a wet weight basis

\begin{tabular}{|lcc|}
\hline & $\begin{array}{c}\mathrm{V}_{\max } \\
\text { nmoles } \mathrm{g}^{-1} \mathrm{~min}^{-1}\end{array}$ & $\begin{array}{c}\mathrm{K}_{\mathrm{m}} \\
\mathrm{mM}\end{array}$ \\
\hline M. spinifera gills & 60.1 & 2.59 \\
Spinach King of Denmark' & 2501 & 0.98 \\
Spinach 'Matador' & 1158 & 0.88 \\
\hline
\end{tabular}

Table 2 gives some kinetic values. Only 1 enzyme was found in tissues that were free of symbionts: sulphate adenylyltransferase activity was present, in relatively small amounts when compared with the gill activity of $M$. spinifera, in the gills of A. islandica and C. gibba, and the foot and mantle of $M$. spinifera. The other 3 enzymes were confined to the gill of $M$. spinifera. The addition of $10 \mathrm{mM}$ fluoride had no effect on adenylyltransferase activity and this, together with the absence of magnesium from the medium and the linear time course of the reaction, indicates that inorganic pyrophosphatase activity was not involved. Adenylylsulphate reductase activity was also assayed in gill extracts from 4 other species of bivalves, Venerupis pullastra (Montagu), Nuculana minuta (Müller), Chlamys varia (L.) and a species of Abra. In all these species the measured activity was less than $0.3 \mathrm{n}$ moles $\mathrm{g}^{-1}$ gill $\mathrm{min}^{-1}$ and such low activity could be due to external contamination of the gills by sediment bacteria. The activity of ribulosebisphosphate carboxylase from the gill of $M$. spinifera was 20- to 40 -fold less than in strongly-growing spinach leaves.

\section{Haemoglobin}

The haemoglobin content of Myrtea spinifera gills was estimated as $0.11 \mathrm{mg}$ per individual, or approxi-

Table 1. Enzyme activities in bivalve tissues, as nmoles of substrate converted to product $\mathrm{g}^{-1}$ wet weight min ${ }^{-1}$ (nmoles $\mathrm{g}^{-1}$ protein $\mathrm{min}^{-1}$ ). Values for individuals

\begin{tabular}{|c|c|c|c|c|c|}
\hline \multirow[t]{2}{*}{ Enzyme } & \multicolumn{2}{|c|}{ Myrtea spinifera } & \multicolumn{2}{|c|}{ Arctica islandica } & \multirow{2}{*}{$\begin{array}{c}\text { Corbula } \\
\text { gibba } \\
\text { gill }\end{array}$} \\
\hline & gill & foot & mantle & gill & \\
\hline $\begin{array}{l}\text { Ribulosebisphosphate } \\
\text { carboxylase }\left(\mathrm{CO}_{2} \text { fixed }\right)\end{array}$ & $28.3,45.5,46.5^{*}$ & nd & nd & 0 & nd \\
\hline $\begin{array}{l}\text { Adenylylsulphate } \\
\text { reductase }\end{array}$ & $\begin{array}{l}15.9,17.8,43.2 \\
(150,158,172)\end{array}$ & $\begin{array}{ll}1.2, & 0.4 \\
(0.9, & 2.2)\end{array}$ & nd & 0 & 0 \\
\hline $\begin{array}{l}\text { Sulphate } \\
\text { adenylyitransferase }\end{array}$ & $\begin{array}{l}203,229,237,293 \\
(1625,1077,1563)\end{array}$ & $\begin{aligned} & 20, 3 \\
&(277,24)\end{aligned}$ & $\begin{array}{c}10 \\
(96)\end{array}$ & $\begin{array}{c}10 \\
(181)\end{array}$ & $\begin{array}{c}10 \\
(252)\end{array}$ \\
\hline $\begin{array}{l}\text { Sulphate } \\
\text { adenylyltransferase (ADP) }\end{array}$ & $\begin{array}{c}89,112,151 \\
(709,527,996)\end{array}$ & 0 & 0 & 0 & 0 \\
\hline
\end{tabular}




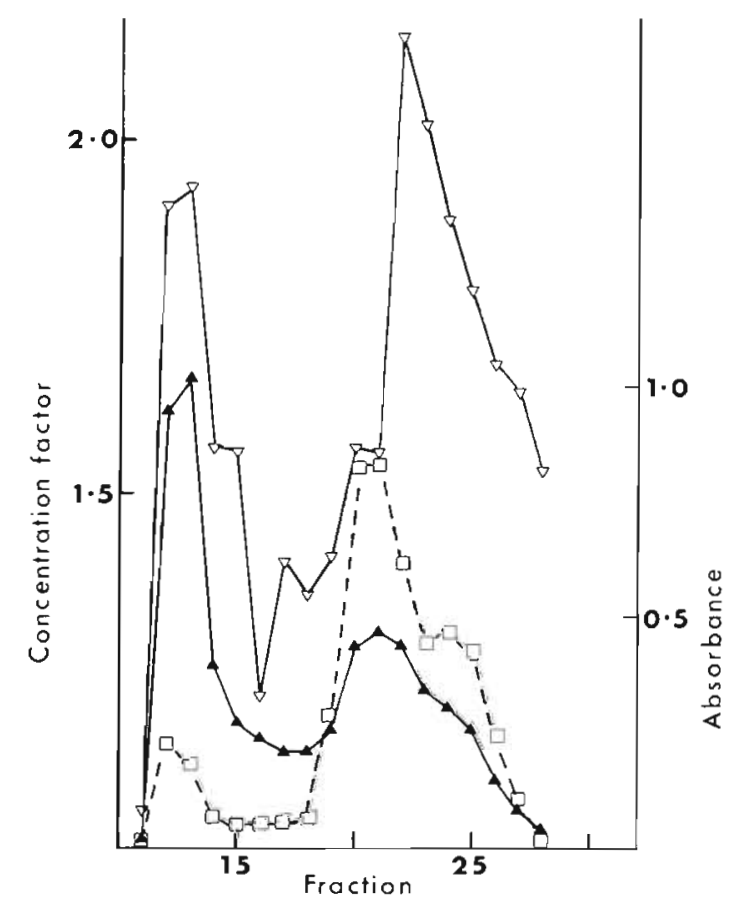

Fig. 6. Myrtea spinifera. Gel filtration of gill extract on Sephadex G-100. Open triangles: sulphide binding (concentration factor) by dialysed fractions; solid triangles: absorbance at $280 \mathrm{~nm}$; open squares: absorbance at $415 \mathrm{~nm}$ (haemoglobin), see text

mately $1 \%$ of the wet weight of the gills. The pigment separated into 2 fractions on the Sephadex G-100 column (Fig. 6), with an apparent molecular weight $\left(M_{r}\right)$ of 36,300 for the first and 22,000 for the second. When Fraction I was diluted and rechromatographed on the same column, 2 peaks were again resolved with values of $36,000 \mathrm{M}_{\mathrm{r}}$ and $22,000 \mathrm{M}_{\mathrm{r}}$. SDS gel electrophoresis of the fractions showed that Fraction I consisted of a single $15,450 \mathrm{M}_{\mathrm{r}}$ component $(\mathrm{Hb}-1)$, while Fraction II resolved into 3 bands of $24,900,16,000$ and $15,450 \mathrm{M}_{\mathrm{r}}$. The second fraction would thus appear to contain some fully dissociated $\mathrm{Hb}-1$, together with another haemoglobin, $\mathrm{Hb}-2$. The results from the Sephadex column suggest that the haemoglobin was already dissociating, and if the subunit weight is taken as $15,450 \mathrm{M}_{\mathrm{r}}$, as
Table 3. Myrtea spinifera. Absorption spectra maxima of gill haemoglobin

\begin{tabular}{|lcccc|}
\hline Protein & $\lambda^{\alpha} \mathrm{nm}$ & & $\lambda^{\beta} \mathrm{nm}$ & $\lambda^{\text {Soret }} \mathrm{nm}$ \\
\hline Oxy Hb & 581 & & 542 & 415 \\
Deoxy Hb & & 555 & & 432 \\
Carbonyl Hb & 571 & & 539 & 421 \\
\hline
\end{tabular}

determined for Hb-1 by SDS gel analysis, the associated form would be at least a dimer.

The absorption maxima of the 2 fractions are shown in Table 3 and are similar to those of other haemoglobins. Oxygen binding was determined on very dilute solutions $(10 \mu \mathrm{M})$ and should therefore be interpreted with caution. At this dilution there was a very high oxygen affinity; at $20^{\circ} \mathrm{C}$ the $\mathrm{P}_{50}$ was 0.27 torr and the Hill coefficient $\left(n_{H}\right)$ 1.96, with no detectable Bohr effect between $\mathrm{pH} 7.52$ and 6.75. Fraction I, Fraction II, and a combination of the two in the same proportions found in the gill extract all had similar $P_{50}$ values and cooperativity.

\section{Sulphide binding by gill proteins}

Results of dialysis of gill proteins from the Sephadex G-100 column against sodium sulphide are shown in Fig. 6. The concentration of sulphide taken up by the proteins is compared with that present in the $10 \mu \mathrm{M}$ dialysis medium and plotted against fraction number alongside total protein $(280 \mathrm{~nm})$ and haemoglobin $(415 \mathrm{~nm})$.

Sulphide is readily bound by the excluded fraction $\left(M_{r}>100,000\right)$ and also by a fraction eluting between the 2 haemoglobin peaks, with an estimated $M_{r}$ of 29,000 . There was no obvious correlation between sulphide binding and the haemoglobin fractions.

\section{Sulphur content of gills}

Estimates of the elemental sulphur content of the gill of Myrtea spinifera are shown in Table 4 . There is a wide range from 0.01 to $0.08 \%$ of the wet weight, but

Table 4. Myrtea spinifera. Elemental sulphur in gills

\begin{tabular}{|c|c|c|c|c|}
\hline Date & Animal condition & Gill colour & $\begin{array}{l}\text { Gill weight } \\
\text { (mg) }\end{array}$ & $\begin{array}{c}\text { Sulphur } \\
\left(\mu \text { moles } g^{-1}\right)\end{array}$ \\
\hline 5. 4. 84 & \multirow{2}{*}{$\begin{array}{l}\text { Partially starved; kept } \\
4 \text { wk in laboratory }\end{array}$} & Dark red & 5.4 & 5.8 \\
\hline 5.4 .84$\}$ & & Dark red & 4.9 & 6.4 \\
\hline 22.6 .84 & \multirow{4}{*}{$\begin{array}{l}\text { Fixed within } 12 \mathrm{~h} \text { of } \\
\text { collection }\end{array}$} & Deep pink & 13 & 25.0 \\
\hline 22.6 .84 & & Deep pink & 15 & 21.4 \\
\hline 22.6 .84 & & Dark red & 7 & 16.5 \\
\hline 22. 6.84) & & Purple red & 14 & 3.3 \\
\hline
\end{tabular}


the higher values were found only in freshly-collected specimens. There is a distinct correlation between colour and sulphur content, the lighter-coloured gills having the most sulphur. We assume that elemental sulphur could be a form of energy storage and indicate 'condition' of the animal/bacteria symbiosis.

\section{Sulphide uptake by gills}

Some results for uptake of ${ }^{35} \mathrm{~S}$ labelled sulphide by gills of Myrtea spinifera and Arctica islandica are shown in Table 5. The apparent rate of fixation was lower in the longer-term experiments, in which it was likely that the concentration of sulphide would have been reduced by uptake and oxidation. Nevertheless, in $M$. spinifera gills the proportion bound to the tissues increased with time, and a small quantity of it was converted to elemental sulphur. The alkaline-buffer electrophoretograms of the methanol extracts show 2 major peaks of sulphur in $M$. spinifera but only 1 , identified as unchanged sulphide, in $A$. islandica, while the acid-phase thin layer chromatograms show a larger number of sulphur-labelled compounds in $M$. spinifera than in $A$. islandica. Thus gills of both species can take up sulphide, but only $M$. spinifera, with its symbionts, is able to metabolize a substantial proportion of the sulphide to other compounds.

\section{Fixation of carbon dioxide}

As shown in Table 6 , the presence of $30 \mu \mathrm{M}$ sulphide increased the total fixation of carbon dioxide by isolated gills of Myrtea spinifera, but not by those of Corbula gibba. The gills of $M$. spinifera were apparently unchanged after $3 \mathrm{~h}$ in $30 \mu \mathrm{M}$ sulphide, but those of C. gibba shrank considerably and appeared to be damaged by the sulphide.

\section{Sediment chemistry}

More details of the chemistry of the Ypsesund sediment will be given in a later paper, but some results that appear relevant to the distribution and biology of Myrtea spinifera are given here. For this purpose we shall consider only the top $15 \mathrm{~cm}$ of the sediment. The sediment at Ypsesund is a silty fine sand containing shell fragments. The water content varies from 50 to $63 \%$ by volume, and organic matter (by loss of weight on ignition at $450^{\circ} \mathrm{C}$ ) amounts to 2.8 to $3.2 \%$ of the dry

Table 5. Accumulation and metabolization of ${ }^{35}$ sulphide by bivalve gills, at $12^{\circ} \mathrm{C}$

\begin{tabular}{|c|c|c|c|c|c|c|}
\hline $\begin{array}{c}\text { Gill } \\
\text { wet } \\
\text { weight } \\
\text { (mg) }\end{array}$ & $\begin{array}{l}\text { Time } \\
\text { (min) }\end{array}$ & In 'soluble' form & $\begin{array}{l}\text { Rate of uptake } \\
\text { In 'bound' form } \\
\left(\mu \text { moles } \mathrm{g}^{-1} \mathrm{~h}^{-1}\right)\end{array}$ & Total & $\begin{array}{l}\% \text { uptake } \\
\text { still present } \\
\text { as sulphide }\end{array}$ & $\begin{array}{l}\% \text { metabolized to } \\
\text { other compounds } \\
\text { (\% elemental sulphur) }\end{array}$ \\
\hline \multicolumn{7}{|c|}{ Myrtea spinifera } \\
\hline 8.2 & 15 & 0.62 & 0.53 & 1.15 & 12 & $88(3.5)$ \\
\hline 8.2 & 30 & 0.38 & 0.36 & 0.74 & 26 & $74 \quad(4.2)$ \\
\hline 15.7 & 135 & 0.15 & 0.24 & 0.39 & 18 & 82 (nd) \\
\hline \multicolumn{7}{|c|}{ Arctica islandica } \\
\hline 45.3 & 15 & 0.83 & 0.44 & 1.27 & 47 & 53 (nd) \\
\hline 118.2 & 143 & 0.33 & 0.09 & 0.41 & 66 & 34 (nd) \\
\hline
\end{tabular}

Table 6. Fixation of ${ }^{14}$ carbon dioxide by bivalve gills exposed to $\mathrm{NaH}^{14} \mathrm{CO}_{3}$ in seawater, with and without $\mathrm{Na}_{2} \mathrm{~S}$ ( 23 to $31 \mu \mathrm{M}$ ), for $3 \mathrm{~h}$ at $12^{\circ} \mathrm{C}$

\begin{tabular}{|c|c|c|c|c|}
\hline \multirow[t]{2}{*}{ Species } & \multicolumn{2}{|c|}{ Without sulphide } & \multicolumn{2}{|c|}{ With sulphide } \\
\hline & $\begin{array}{c}\text { Fixation } \\
\text { rate } \\
\text { (nmoles } \mathrm{g}^{-1} \mathrm{~min}^{-1} \text { ) }\end{array}$ & $\begin{array}{c}\text { Gill } \\
\text { wet weight } \\
\text { (mg) }\end{array}$ & $\begin{array}{c}\text { Fixation } \\
\text { rate } \\
\text { (nmoles } g^{-1} \mathrm{~min}^{-1} \text { ) }\end{array}$ & $\begin{array}{l}\text { Gill } \\
\text { wet weight } \\
\text { (mg) }\end{array}$ \\
\hline \multirow{2}{*}{ Myrtea spinifera } & 0.96 & 7.2 & 3.07 & 6.4 \\
\hline & 0.56 & 4.7 & 4.26 & 3.7 \\
\hline \multirow{2}{*}{ Corbula gibba } & 0.32 & 5.7 & 0.44 & 4.8 \\
\hline & 0.75 & 6.0 & 0.49 & 3.7 \\
\hline
\end{tabular}


weight. Uncorrected redox values become negative a few $\mathrm{mm}$ below the sediment surface and range from -200 to $-300 \mathrm{mV}$ between $3 \mathrm{~cm}$ and $15 \mathrm{~cm}$ depth, with a pH between 7 and 8 . Sediment temperature (measured after retrieval) was 5.3 to $5.6{ }^{\circ} \mathrm{C}$ in February and ca. $8^{\circ} \mathrm{C}$ in June 1984 . Van Veen grab samples in March showed some oxygen in the near bottom water, but below $5 \mathrm{~mm}$ depth in the sediment the oxygen meter read zero.

The level of free sulphide in expressed interstitial water differed according to the method of collection. Two cores from which water was collected by pressure filtration with nitrogen through a $0.2 \mu \mathrm{m}$ filter showed no detectable dissolved sulphide in the upper $10 \mathrm{~cm}$. The limit of detection was approximately $1 \mu \mathrm{M}$. One core was less than $1 \mu \mathrm{M}$, the other gave a value of about $1.5 \mu \mathrm{M}$ in the 10 to $15 \mathrm{~cm}$ depth zone. Higher values for dissolved sulphide were given by interstitial water displaced by trichlorotrifluoroethane, from $<0.5$ $\mu \mathrm{M}$ to $4.5 \mu \mathrm{M}$ for one core, and from $5.7 \mu \mathrm{M}$ to $11 \mu \mathrm{M}$ for another. This interstitial water was slightly turbid and, we suspect that the turbidity was partly due to colloidal ferrous sulphide (Volkov \& Rozanov 1983) since the most turbid samples usually gave the highest values. Hence the 'dissolved sulphide' values obtained by the Cline method for displaced interstitial water are probably erroneously high. We have obtained free sulphide levels below $1.0 \mu \mathrm{M}$ in pore water filtered from similar sediments, and we believe that this value is close to the maximum dissolved sulphide concentration of the interstitial sediment water at Ypsesund. Even this value may be inflated if, as seems likely, finely divided ferrous sulphide passes through the filters used. Additional evidence for the low level of free sulphide can be obtained by olfaction. It has already been reported that the Ypsesund sediment does not smell obviously of sulphide (Southward et al. 1979) and a keen nose is required to detect a very faint smell under field conditions. When such a smell was compared with freshly diluted solutions of sodium sulphide in sea water the limit of olfaction was found to be about $0.1 \mu \mathrm{M}$. The smell of $0.5 \mu \mathrm{M}$ sodium sulphide could be detected quite easily and appeared stronger than that of freshly disturbed sediment.

In contrast to the free sulphide concentration, there was a sharp increase in acid-labile sulphide with depth in the Ypsesund sediment. From zero at the surface this bound sulphide increased to $3.5 \mu$ moles $\mathrm{dm}^{-3}$ of sediment at $1 \mathrm{~cm}, 315 \mu$ moles $\mathrm{dm}^{-3}$ at $2 \mathrm{~cm}$ and $625 \mu$ moles $\mathrm{dm}^{-3}$ at $11 \mathrm{~cm}$. However, the concentration decreased sharply below $25 \mathrm{~cm}$. The concentrations of thiosulphate, trithionate and tetrathionate in the pore water were below, or not significantly different from, the limit of detection of approximately $10 \mu \mathrm{M}$.

The concentration of iron, soluble in $10 \%$ hydro- chloric acid, ranged from 80 to $108 \mathrm{~m}$ moles $\mathrm{dm}^{-3}$ of sediment, and of manganese from 1.2 to $1.4 \mathrm{~m}$ moles $\mathrm{dm}^{-3}$. The highest values for both elements were found in the upper $2.5 \mathrm{~cm}$ of the sediment.

\section{DISCUSSION}

The bacteria in the subfilamentar region of the gill of Myrtea spinifera appear to be chemolithotrophic sulphur oxidizers. This conclusion is based on the presence of ribulosebisphosphate carboxylase, adenylyl sulphate reductase and sulphate adenylyltransferase (ADP), together with elemental sulphur, in gill extracts. These three enzymes have not been reported from animal tissues that lack symbiotic bacteria, and were absent from other bivalves living in the Ypsesund sediment, Corbula gibba and Arctica islandica, which have no symbiotic bacteria in their gills.

Another sulphur-metabolizing enzyme, sulphate adenylyltransferase, was abundant in the gill of M. spinifera, but occurred also in lesser quantities in the foot and mantle tissues which lack symbionts. It was also present in small amounts in the gills of Corbula gibba and Arctica islandica. However, the activity in the gill of $M$. spinifera was much higher than in the other tissues, suggesting that most of the activity originated in the endosymbiotic bacteria. The presence of elemental sulphur in the gill of $M$. spinifera also indicates active sulphur metabolism for, although quite small amounts are reported, the analytical method used may underestimate total membrane-bound sulphur: for example, in Thiobacillus concretivorus only 5 to $10 \%$ of the sulphur can be extracted by carbon disulphide (Moriarty \& Nicholas 1970).

In comparison with known sulphur-oxidizing bacteria, the symbionts from the gills of Myrtea spinifera are morphologically closest to the genera Thiobacterium and Thiovulum (La Rivière \& Schmidt 1983). Members of both these genera are oval and spherical and contain numerous sulphur inclusions. Thiovulum is a motile slime-producer, while Thiobacterium builds up rounded or branching colonies enclosed in slime. A capacity for slime production might be a useful feature in a symbiont required to produce extracellular organic compounds for the nourishment of its host.

Myrtea spinifera gill resembles the gill of Solemya reidi (Felbeck et al. 1981, Felbeck 1983) and the trophosome of Riftia pachyptila (Cavanaugh et al. 1981, Felbeck 1981) in containing bacteria which, from the presence of ribulosebisphosphate carboxylase and adenylylsulphate reductase, are probably chemolithotrophic sulphur oxidizers. There is evidence for this putative symbiosis in other bivalves: Solemya 
velum has bacteria in the gill, possesses ribulosebisphosphate carboxylase and shows enhanced fixation of bicarbonate in the presence of free sulphide (Cavanaugh 1983); the gill of Calyptogena pacifica also contains ribulosebisphosphate carboxylase, a high activity of sulphate adenylyltransferase and oxidizes sulphide (Felbeck et al. 1981, Childress \& Mickel 1982). Other bivalves that have bacteria in the gill and show ribulosebisphosphate carboxylase activity and high levels of sulphate adenylyltransferase are Calyptogena magnifica and Lucinoma annulata (Felbeck et al. 1981, Cavanaugh 1983) and Codakia orbicularis (Berg \& Alatolo 1984). Adenylylsulphate reductase could not be detected in $C$. orbicularis gill extracts (Berg \& Alatolo 1984).

The gutless marine oligochaete Phallodrilus leukodermatus has numerous Gram-negative bacteria beneath the cuticle of its epidermis (Giere 1981), shows ribulosebisphosphate carboxylase activity, high activities of sulphate adenylyltransferase and sulphite oxidase, but no detectable adenylylsulphate reductase (Felbeck et al. 1983). This worm lives close to the redox potential discontinuity layer in coral sands and reaches a maximum population density where the free sulphide concentration is 5 to $32 \mu \mathrm{M}$ (Giere et al. 1982). However, it ranges from completely oxidized sand to deep in the reducing layer without access to oxygen and may migrate between the layers (Giere et al. 1982. Giere pers. comm.).

The question of access to oxygen brings us to the function of haemoglobin in the gill of Myrtea spinifera. The haemoglobin extracted was heterogenous, with a polymeric fraction, at least dimeric, as well as a monomeric fraction. The polymer undoubtedly dissociated on dilution, but the subunit size for the majority of the material, $15,450 \mathrm{M}_{\mathrm{r}}$ and for another apparently distinct haemoglobin of $16,100 \mathrm{M}_{\mathrm{r}}$ are quite similar to those of other haemoglobins. The distribution of haemoglobin in tissues of bivalves appears to be somewhat capricious (Terwilliger \& Terwilliger in press), but haemoglobin has already been described from the gill of another lucinid bivalve, Phacoides pectinatus (Lucina jamaicensis), and it is probably present in another member of the family, Codakia orbicularis (Read 1962, 1965, Berg \& Alatolo 1984). The gills of the protobranch Solemya velum also contain haemoglobin (Doeller et al. 1983). The haemoglobin in the gill of $P$. pectinatus closely resembles that from the gill of $M$. spinifera in that it is heterogeneous with a monomeric fraction of $M_{\mathrm{r}} 14,500$ and a polymeric fraction which dissociates on dilution. The haemoglobin from $P$. pectinatus also has high oxygen affinity, $\mathrm{P}_{50}=0.19$ torr at $25^{\circ} \mathrm{C}, \mathrm{n}_{\mathrm{H}}=1$, fairly close to the values given here for M. spinifera $\left(\mathrm{P}_{50}=0.27\right.$ torr at $\left.20^{\circ} \mathrm{C}, \mathrm{n}_{\mathrm{H}}=1.96\right)$. Doeller et al. (1983) reported an in situ oxygen affinity for $S$. velum haemoglobin of $P_{50}=1$ to 3 torr, and since the haemoglobin of $M$. spinifera dissociates on dilution, it is possible that its actual in situ affinity for oxygen is less than reported here. Nevertheless, there is no doubt that all the bivalve gill haemoglobins investigated have quite high affinities for oxygen.

It has been suggested that the haemoglobin of the pogonophore Riftia pachyptila may function as a carrier of sulphide (Arp \& Childress 1983). However, it seems unlikely that the haemoglobin of Myrtea spinifera has such a function, since we could find no evidence for the binding of sulphide (Fig. 6). Two possible functions remain for the haemoglobin: (1) it could act as a store for oxygen during periods of closure of the inhalent tube and while the animal was burrowing; (2) it could have a function arising from the finding that sulphur-oxidizing bacteria are frequently microaerophilic (Jørgensen 1982) - the haemoglobin might be needed as a buffer to protect the symbionts from excess oxygen which could interfere with their autotrophic processes and lead to spontaneous oxidation of free sulphide. We are thus suggesting that one of the possible functions of haemoglobin in Solemya velum and the 2 lucinids might be comparable to that of leghaemoglobin of the Rhizobium-legume root symbiosis (Wittenberg et al. 1974). The oxygen concentration at the bacteroid surface in legumes is controlled by leghaemoglobin ( $\mathrm{P}_{50}=0.55$ torr) to only $10 \mathrm{nM}$ (Bergersen \& Goodchild 1973). A further possible function of the haemoglobin, for which we have no data, might be to protect the animal cells from excessive depletion of the oxygen levels when the bacteria are actively oxidizing sulphur compounds.

With the exception of Myrtea spinifera, and apparently, on occasion, Phallodrilus leukodermatus, all the other organisms that possess endosymbiotic bacteria and whose environmental chemistry has been studied, live in habitats with high concentrations of free sulphide, ranging from $160 \mu \mathrm{M}$ to $25 \mathrm{mM}$ (see Felbeck 1981, 1983 for references). Solemya velum has been reported from eelgrass beds that 'smelled strongly of hydrogen sulphide' (Cavanaugh 1983) and Codakia orbicularis occurs 5 to $10 \mathrm{~cm}$ deep in beds of sea-grass Thalassia testudinarium in 'a zone of high sulphide concentrations' (Berg \& Alatolo 1984). Our measurements show the upper limit of dissolved sulphide in the sediment at Ypsesund is $1.5 \mu \mathrm{M}$, and the concentration may be as low as $0.5 \mu \mathrm{M}$. M. spinifera therefore lives in sediments where the dissolved sulphide concentrations are 2 to 4 orders of magnitude lower than those reported for other habitats containing bivalves with similar chemolithotrophic sulphide-oxidizing symbionts. It seems probable that the low levels of dissolved sulphide in the habitat of $M$. spinifera are connected with the high concentrations of available iron 
and manganese. These ions, together with the relatively high $\mathrm{pH}$ (for anoxic sediments), may keep the concentrations of sulphydryl ions low (Davison 1980). Nevertheless, the concentration of bound sulphide released by dilute acids, and presumed to be present mostly as ferrous sulphide (Volkov \& Rozanov 1983), is considerably lower than reported from other marine sediments (Kaplan et al. 1963, Jørgensen 1977, Novitsky et al. 1980, Troelsen \& Jørgensen 1982).

In the absence of data on the rate of sulphate reduction in the Ypsesund sediment we cannot say if the low level of available sulphide is the result of a low rate of production or a high rate of oxidation. The presence of several species of animals with tissues containing symbiotic bacteria will increase the volume of habitat in which sulphide-oxidizing bacteria can exist - they are normally restricted to the oxic/anoxic interface - and could enhance the overall rate of sulphide oxidation in the sediment.

The energy needs of the host animal must be considered. Lucinid bivalves (including Myrtea spinifera, Lucinoma borealis and Codakia orbicularis are filter feeders, but have remarkably inefficient sorting mechanisms, which permit large particles as well as small ones to enter the mouth and reach the stomach. The stomach is simple and the gut short. Allen (1958) concluded that these anatomical modifications were adaptations to a scarce food supply, allowing the use of large particles normally rejected by other bivalves. Uptake of dissolved organic matter (DOM) may play a small part in the nutrition of $M$. spinifera, but is unlikely to make a substantial contribution unless there is an unexpectedly high concentration of DOM in the inflowing water (Wright 1982). The symbiotic bacteria would be useful if they could supply part or most of the energy needs of the host.

Microbial processes and the chemistry of sulphide oxidation have been reviewed by Jannasch (1983) and Kelly (1982), while Kelly \& Kuenen (1984) have calculated the energetics of sulphide-oxidizing symbionts in supplying organic carbon to the host animal. We can extend the calculations of Kelly \& Kuenen (1984) to provide estimates of the flux rate required to support the population of Myrtea spinifera. These authors estimated that each mole of sulphur oxidized would yield 0.2 mole of carbon fixed, and they assumed a conversion efficiency of $20 \%$, from bacterium to host. The density of $M$. spinifera at Ypsesund is $25 \mathrm{~m}^{-2}$; the average wet weight of tissue is $65 \mathrm{mg}$ individual ${ }^{-1}$; we assume that sulphide is drawn from the upper $5 \mathrm{~cm}$ of sediment only. Conversion of wet weight to carbon on a $10 \%$ basis gives $6.5 \mathrm{mg}$ carbon individual ${ }^{-1}$, which would correspond to oxidation and conversion of 13.54 mmoles sulphur. If we allow from 2 to $10 \mathrm{yr}$ for growth to adult size then the sulphur utilization rate would be
155 to 773 nmoles $h^{-1}$. The measured uptake by excised gills in vitro was much lower than this, from 6.0 to 9.4 nmoles $\mathrm{h}^{-1}$, according to incubation time (Table 5), but it is probable that the incubation conditions, including oxygen concentration, were far from optimal. This uptake rate is equivalent to $0.26 \mu$ moles $\mathrm{h}^{-1} \mathrm{~g}^{-1}$ body weight and compares with rates of up to $0.5 \mu$ moles $\mathrm{h}^{-1} \mathrm{~g}^{-1}$ for Calyptogena pacifica (Childress \& Mickel 1982) and 1.1 to $1.7 \mu$ moles $\mathrm{h}^{-1} \mathrm{~g}^{-1}$ for Solemya reidi (Felbeck 1983).

The sediment flux rate required to maintain the estimated needs of 25 Myrtea spinifera $\mathrm{m}^{-2}$ can be calculated as 77 to 386 nmoles sulphide $l^{-1}$ sediment $\mathrm{h}^{-1}$, not allowing for maintenance metabolism or reproductive effort. If we assume the dissolved sulphide concentration in the environment is $<1 \mu \mathrm{M}$ then adult M. spinifera would have to pump between 150 and 770 ml of interstitial water $\mathrm{h}^{-1}$ to obtain sufficient sulphide. These volumes are more than an order of magnitude higher than would be expected from a bivalve of the size of $M$. spinifera (Ola Vahl pers. comm.). It is possible therefore that the free sulphide concentration in the immediate vicinity of the animal may be considerably higher than $1 \mu \mathrm{M}$. The zone of maximum sulphide production in coastal sediments is normally within $5 \mathrm{~cm}$ of the surface (Reeburgh 1980, Devol et al. 1984, Troelsen \& Jørgensen 1982) and M. spinifera may further raise the production rate in this layer by enriching the neighbouring sediment with a deposit of pseudofaeces (Fig. 1) which might be a nutrient source for sulphate-reducing bacteria. The sediment around the shell is black, apart from the oxidized layer around the inlet tube. Another possibility is suggested by the observation that $M$. spinifera constructs a new inlet every few days. The oxygen in the inhalent water appears to oxidize the iron sulphides in the sediment around the tube (Fig. 2). The partial oxidation products formed, for example thiosulphate, could diffuse into the inhalent current and contribute to the energy sources for the endosymbiotic bacteria. The presence of elemental sulphur in the gills of freshly collected animals suggests that the bacteria are normally well supplied with reduced sulphur compounds, and this reinforces the argument for access to concentrations higher than the dissolved sulphide levels measured in the interstitial water.

Myrtea spinifera is widely distributed in shallow sea sediments and in the Fjords (Tebble 1966, pers. obs., communications from A. Fosshagen, P. Johannessen, O. Vahl). In contrast it is uncommon in estuaries and has not been found in the shallow Danish inlets where the sediments contain high levels of sulphide (Jensen \& Spärck 1934, Jørgensen 1982). We suggest that the symbiosis represented by $M$. spinifera and its associated bacteria has developed as an adaptation to life in 
low sulphide sediments, which are widely distributed in the natural environment (Volkov \& Rozanov 1983). This type of symbiosis could be more widespread than hitherto suspected.

Acknowledgements. We express our thanks to our colleagues in Norway, particularly Torleiv Brattegard, Per Johannessen and Ola Vahl for advice and help. R. L. Barrett, G. Burt and R. Ling assisted with field-work and/or laboratory preparations and analyses, and D. Nicholson took the photograph for Fig. 2. We are particularly indebted to the crews of the research vessels 'Fridtjof Nansen' and 'August Brinkmann DE' for assistance in sampling. N.B.T. and R.C.T. were partially supported by NSF grant PCM 82-07548.

\section{LITERATURE CITED}

Allen, J. A. (1953). Function of the foot in the Lucinacea. Nature, Lond. 171: 1117-1118

Allen, J. A. (1958), On the basic form and adaptations to habitat in the Lucinaceae (Eulamellibranchia). Phil. Trans. R. Soc. B 241: 421-484

Arp, A., Childress, J. (1983). Sulfide binding by the blood of the hydrothermal vent tube worm Riftia pachyptila. Science 219: 295-297

Atkins, D. (1937). On the ciliary mechanisms and interrelationships of Lamellibranchiata. III. Types of lamellibranch gills and their food currents. Q. J. microsc. Sci. 79: $374-421$

Baddiley, J., Buchanan, J. G., Letters, R. (1957). Synthesis of adenosine $5^{\prime}$-sulfatophosphate. A degradation product of an intermediate in the enzymic synthesis of sulfuric esters. J. chem. Soc. 1067-1071

Benesch, R., MacDuff, G., Benesch, R. E. (1965). Determination of oxygen equilibrium with a versatile new tonometer. Analyt. Biochem. 11: 81-87

Berg, C. J., Alatolo, P. (1984). Potential of chemosynthesis in molluscan mariculture. Aquaculture 39: 165-179

Bergersen, F. J., Goodchild, D. J. (1973). Cellular locations and concentrations of leghemoglobin in soybean root nodules. Aust. J. biol. Sci. 26: 741-756

Cavanaugh, C. M. (1983). Symbiotic chemoautotrophic bacteria in marine invertebrates from sulphide-rich habitats. Nature, Lond. 302: 58-61

Cavanaugh, C. M., Gardiner, S. L., Jones, M. L., Jannasch, H. W., Waterbury, J. B. (1981). Prokaryotic cells in the hydrothermal vent tube worm Riftia pachyptila Jones: possible chemoautotrophic symbionts. Science 213: 340-342

Childress, J. J., Mickel, T. J. (1982). Oxygen and sulfide consumption rates of the vent clam Calyptogena pacifica. Mar. Biol. Lett. 3: 73-79

Cline, J. D. (1969). Spectrophotometric determination of hydrogen sulphide in natural waters. Limnol. Oceanogr. 14: $454-458$

Davison, W. (1980). A critical comparison of the measured solubilities of ferrous sulphide in natural waters. Geochim. cosmochim. Acta 44: 802-808

Devol, A. H., Anderson, J. J., Kuivila, K., Murray, J. W. (1984). A model for coupled sulphate reduction and methane oxidation in the sediments of Saanich Inlet. Geochim. cosmochim. Acta 48: 993-1004

Doeller, J. E., Kraus, D. W., Colacino, J. M. (1983). The presence of hemoglobin in Solemya velum (Bivalvia, Protobranchia). Am. Zool. 22: 976
Fawcett, D. W. (1966). An atlas of fine structure. The cell, its organelles and inclusions. Saunders, Philadelphia

Felbeck, H. (1981). Chemoautotrophic potential of the hydrothermal vent tube worm Riftia pachyptila Jones (Vestimentifera). Science $213: 340-342$

Felbeck, H. (1983). Sulfide oxidation and carbon fixation by the gutless clam Solemya reidi: an animal-bacteria symbiosis. J. comp. Physiol. 152: 3-11

Felbeck, H., Childress, J. J., Somero, G. N. (1981). CalvinBenson cycle and sulphide oxidation enzymes in animals from sulphide-rich habitats. Nature, Lond. 293: 291-293

Felbeck, H., Liebezeit, G., Dawson, R., Giere, O. (1983). $\mathrm{CO}_{2}$ fixation in tissues of marine oligochaetes (Phallodrilus leukodermatus and $P$. planus) containing symbiotic chemoautotrophic bacteria. Mar. Biol. 75; 187-189

Fliermans, C. B., Brock, T. D. (1973). Assay of elemental sulfur in soil. Soil. Sci. 115: 120-122

Giere, O. (1981). The gutless marine oligochaete Phallodrilus leukodermatus. Structural studies on an aberrant tubificid associated with bacteria. Mar. Ecol. Prog. Ser. 5: 353-357

Giere, O., Liebezeit, G., Dawson, R. (1982). Habitat conditions and distribution pattem of the gutless oligochaete Phallodrilus leukodermatus. Mar. Ecol. Prog. Ser. 8: 291-299

Jannasch, H. W. (1983). Microbial processes at deep sea hydrothermal vents. In: Rona, P. A., Bostrom, K, Laubier, L., Smith, K. L. (ed.) Hydrothermal processes at seafloor spreading centers. Plenum Press, New York, London, p. $677-709$

Jannasch, H. W., Wirsen, C. O. (1979). Chemosynthetic primary production at East Pacific sea floor spreading centers. Bioscience 29: 592-598

Jensen, A. S., Spärck, R. (1934). Bløddyr II. Saltvandsmuslinger. Danmarks Fauna, Copenhagen

Jørgensen, B. B. (1977). The sulfur cycle of a marine coastal sediment (Limfjorden, Denmark). Limnol. Oceanogr. 22: $814-832$

Jørgensen, B. B. (1982). Ecology of the bacteria of the sulphur cycle with special reference to anoxic-oxic interface environments. Phil. Trans. R. Soc. Lond. B 298: 429-560

Kaplan, I. R., Emery, K. O., Rittenberg, S. C. (1963). The distribution and isotopic abundance of sulphur in recent marine sediments off southern California. Geochim. cosmochim. Acta 27: 297-331

Kelly, D. P. (1982). Biochemistry of the chemolithotrophic oxidation of inorganic sulphur. Phil. Trans. R. Soc. Lond. B 298: 499-529

Kelly, D. P., Kuenen, J. G. (1984). Ecology of the colourless sulphur bacteria. In: Codd, G. A. (ed.) Aspects of microbial nutrition and ecology. Academic Press, New York, p. 211-240

Kelly, D. P., Chambers, L. A., Tudinger, P. A. (1969). Cyanolysis and spectrophotometric estimation of trithionate in a mixture with thiosulphate and tetrathionate. Analyt. Chem. 41: 898-901

Kinniburgh, D. G., Miles, D. L. (1983). Extraction and chemical analysis of interstitial water from soils and rocks. Environ. Sci. Tech. 17: 362-368

Laemmli, U. K. (1970). Cleavage in structural proteins during the assembly of the head of bacteriophage T4. Nature, Lond. 227: 680-685

La Rivière, J. W. M., Schmidt, K. (1983). Morphologically conspicuous sulfur-oxidizing Eubacteria. In: Starr, M. P., Stolp, H., Trüper, H. G., Balows, A., Schlege, H. G. (ed.) The prokaryotes. Springer-Verlag, Berlin, p. 1037-1048

Moriarty, D. J. W., Nicholas, D. J. D. (1970). Products of sulphide oxidation in extracts of Thiobacillus concretivorus. Biochim. biophys. Acta 197: 143-151 
Munson, D. A. (1977). Simplified method for the determination of acid-soluble sulfides in marine sediments. Mar. Biol. 40: 145-150

Novitsky, J. A., Scott, I. R., Kepkay, P. E. (1980). Effects of iron, sulfur, and microbial activity on aerobic to anaerobic transitions in marine sediments. Geomicrobiol. J. 2: 211-223

Peck, H. D., Deacon, T. E., Davidson, J. T. (1965). Studies on adenosine 5 ' -phosphosulphate reductase from Desulfovibriio desulfuricans and Thiobacillus thioparus I. The assay and purification. Biochim. biophys. Acta 96: 429-446

Read, K. R. H. (1962). The hemoglobin of the bivalved mollusc Phacoides pectinatus Gmelin. Biol. Bull. mar. biol. Lab., Woods Hole 123: 605-617

Read, K. R. H. (1965). The characterization of the hemoglobins of the bivalve mollusc Phacoides pectinatus (Gmelin). Comp. Biochem. Physiol. 15: 137-158

Reeburgh, W. S. (1980). Anaerobic methane oxidation: rate depth distribution in Skan Bay sediments. Earth Planet. Sci. Lett. 47 : 345-352

Southward, A. J., Southward, E. C., Brattegard, T., Bakke, T. (1979). Further experiments on the value of dissolved organic matter as food for Siboglinum fiordicum (Pogonophora). J. mar. biol. Ass. U.K. 59: 133-148

Southward, A. J., Southward, E. C., Dando, P. R., Rau, G. H., Felbeck, H., Flügel, H. J. (1981). Bacterial symbionts and low ${ }^{13} \mathrm{C} /{ }^{12} \mathrm{C}$ ratios in tissues of Pogonophora indicate unusual nutrition and metabolism. Nature, Lond. 293 : 616-620

Southward, E. C. (1982). Bacterial symbionts in Pogonophora. J. mar. biol. Ass. U. K. 62: 889-906

Tebble, N. (1966). British bivalve seashells. The British Museum (Natural History), London

Terwilliger, R. C., Terwilliger, N. B. (1985). Molluscan hemoglobins. Comp. Biochem. Physiol., in press

Troelsen, H., Jørgensen, B. B. (1982). Seasonal dynamics of elemental sulphur in two coastal sediments. Estuar. coast. Shelf. Sci. 15: 255-266

Tsang, M. L., Lemieux, J., Schiff, J. A., Bojarski, T. B. (1976). Preparation of adenosine 5'-phosphosulfate (APS) from adenosine $3^{\prime}$-phosphate $5^{\prime}$-phosphosulfate (PAPS) prepared by an improved procedure. Analyt. Biochem. 74: 623-626

Volkov, I. I., Rozanov, A. G. (1983). The sulphur cycle in the oceans. In: Ivanov, M. V., Freny, J. R. (ed.) The global biogeochenical sulphur cycle. Wiley \& Sons, Chichester, p. $357-448$

Wittenberg, J. B., Bergerson, B. J., Appleby, C. A., Turner, G. L. (1974). Facilitated oxygen diffusion: the role of leghemoglobin in nitrogen fixation by bacteroids isolated from soybean nodules. J. biol. Chem. 249: 4057-4066

Wright, S. H. (1982). A nutritional role for amino acid transport in filter-feeding invertebrates. Am. Zool. 22: 621-634

This paper was submitted to the editor; it was accepted for printing on January 12,1985 